\title{
Strategic Communication and the Marketization of Educational Exchange
}

\author{
Hamilton Bean \\ University of Colorado Denver
}

\begin{abstract}
This article describes how the marketization discourse that typifies U.S. strategic communication also influences the meanings and practices of educational exchange. Through an analysis of five presentations and 34 program evaluations provided by the U.S. State Department's Bureau of Educational and Cultural Affairs, this article explores the risks associated with marketization discourse for the development of mutual understanding and peace.
\end{abstract}

Keywords: Educational exchange, public diplomacy, discourse, marketization, engagement

\section{Introduction}

The Fulbright educational exchange program has been called "one of the most enlightened initiatives undertaken" by the United States. ${ }^{1}$ On August 1, 1946, President Harry S. Truman signed into law the Fulbright Act, which was intended to promote international goodwill through the exchange of students in the fields of education, culture, and science. Through the development of "mutual understanding," citizens of the United States and other countries would, ideally, cultivate peaceful relations. The Fulbright program's promotion of goodwill, mutual understanding, and peace was also strategic. Specifically, the Fulbright Act's proponents claimed that by developing U.S. citizens who possessed in-depth knowledge of politically and economically important countries and regions, educational exchange would increase the security of the United States.

The tension between policies created for mutual benefit versus mostly for one's own strategic gain characterizes public relations. ${ }^{2}$ Whether in the context of organizations or states, so-called "hemispheric communicators" in the fields of public relations, public affairs, and public diplomacy walk a fine line between mutual- and self-advantage, and as a result, they tend to "express messages that speak to only half the landscape. Like the shining moon, they present only the bright side and leave the dark side hidden". ${ }^{3}$ For Moloney, "Modern PR is competitive communication seeking advantage for its principals and using many promotional techniques, visible and invisible, outside of paid advertising". ${ }^{4}$ Moloney identifies public relations as a form of "weak propaganda," that is, the "the one-sided presentation of data, belief, an idea, behaviour, policy, a good or service in order to gain attention and advantage

\footnotetext{
Hamilton Bean, Associate Professor, Department of Communication, University of Colorado Denver. Email: hamilton.bean@ ucdenver.edu.

1 "An informal history of the Fulbright Program," Bureau of Educational and Cultural Affairs, http://eca.state.gov/fulbright/ about-fulbright/history/early-years.

D. McKie and D. Munshi, Reconfiguring Public Relations: Ecology, equity, and enterprise (London: Routledge, 2007).

J. Jensen, Ethical Issues in the Communication Process (New Jersey: Lawrence Erlbaum, 1997), 68.

K. Moloney, Rethinking Public Relations (New York: Routledge, 2006), 165.
} 
for the message sender". ${ }^{5}$ Such propaganda is "weak," however, in that within pluralistic and democratic societies, it must compete for public attention with other self-advantaging messages.

This article argues that the U.S. State Department's Bureau of Educational and Cultural Affairs' (ECA) program evaluations are a form of weak propaganda. Specifically, ECA's rhetoric evinces the influence of marketization: "market-oriented principles, values, practices, and vocabularies". ${ }^{6}$ Leitch and Davenport explained that marketization "involves the introduction of economic factors as the basis for decision-making as well as deployment of the techniques of business such as marketing and public relations". ${ }^{7}$ Marketization also refers to the "process of penetration of essentially market-type relationships into arenas not previously deemed part of the market". ${ }^{8}$ Marketization bears a family resemblance to other neoliberal discourses such as "enterprise," "entrepreneurialism," "market evangelism" and "Total Quality Management". ${ }^{9}$ Inflected in the vernacular of marketization, ECA's evaluations reflect and reinforce taken-for-granted assumptions about educational exchange that may subtly hinder the development of deeper mutual understanding and peace.

Let me be clear: Educational exchange certainly makes useful contributions to crosscultural awareness, sensitivity, security, and competitiveness. I am more concerned in this article, however, in marketization's role in shaping the meanings and practices of educational exchange in the context of U.S. public diplomacy and strategic communication. Specifically, the terrorist attacks of 9/11 ruptured traditional conceptualizations of educational exchange, shifting the emphasis in the United States from mutual benefit toward strategic selfadvantage. ${ }^{10}$ This shift toward strategic communication involved the intensification of neoliberal policies and the proliferation of marketing-oriented discourses across multiple sectors and institutions, the consequences of which are still not well understood. ${ }^{11}$ This article considers some the risks that marketization discourse poses for international educational exchange stakeholders.

The structure of this article is as follows. First, it provides a discourse-oriented theoretical framework. It then uses that framework to describe how $9 / 11$ served as a catalyst that transformed the meanings and practices of educational exchange in the United States. This transformation coincided with broader policy shifts toward strategic communication, marketization, and engagement within the public diplomacy arena. Third, the article explains how marketization discourse influences educational exchange program evaluation at ECA. It concludes with a summary of the risks associated with marketization for the development of mutual understanding, reflexivity, and peace.

Moloney, Rethinking Public Relations, 167.

M. Simpson and G. Cheney, "Marketization, Participation and Communication within New Zealand Retirement Villages: A critical-rhetorical and discursive analysis," Discourse and Communication 1 (2007): 191.

S. Leitch and S. Davenport, "The Politics of Discourse: Marketization of the New Zealand science and innovation system," Human Relations 58 (2005): 893.

8 Simpson and Cheney, "Marketization, Participation," 191.

A. I. Marcus, “'Would you like fries with that, Sir?' The evolution of management theories and the rise and fall of total quality management within the American federal government," Management \& Organizational History 3 (2008): 311-38.

10 D. Campbell, "International Education and the Impact of the 'War on Terrorism'," Irish Studies in International Affairs 16 (2005): 127-54

11 J. Gygax and N. Snow, "9/11 and the Advent of Total Diplomacy: Strategic communication as a primary weapon of war," Journal of 9/11 Studies 38 (2013): 1-29; Marcus, “'Would you like fries with that, Sir?”" 


\section{Discourse}

Discourse is a term not easily summarized because different speakers use it in multiple (and at times conflicting) ways. This article focuses on the U.S. State Department's "organizational discourse," a term that similarly escapes easy summary but generally refers to talk and text within organizational contexts, rather than smaller interpersonal or group, or larger macro-social contexts. The scholarly focus on discourse can be traced to the "linguistic turn" that shook the foundations of the humanities and social sciences during the latter half of the twentieth century. In response to the idea that language constructs social reality, the practice of "discourse analysis" developed within and across the fields of sociology, social psychology, anthropology, linguistics, philosophy, communication, and literary studies. Discourse analytic methods involve the use of interpretive, critical, or postmodern perspectives. ${ }^{12}$ Organizational discourse analysis has thus grown from diverse theoretical roots and methodological approaches. The definition of organizational discourse used in this article is "the structured collections of texts embodied in the practices of talking and writing...that bring organizationally related objects into being as these texts are produced, disseminated and consumed". ${ }^{13}$

Discourse scholars tend to conceptualize discourse as both reflective and constitutive of social reality. ${ }^{14}$ This conceptualization affirms Foucauldian assumptions regarding the way that language "bears down" on individuals, shapes overall societal conditions, and influences what speakers can say or not say about a given phenomenon.$^{15}$ To explain how a discourse "works," however, an analyst generally must demonstrate how people in a particular time and place bring forth, maintain, or transform a construction of social reality through the linguistic resources used in speech and writing. A discourse becomes powerful and influential when its underlying assumptions become taken-for-granted or institutionalized. However, even entrenched discourses can serve as a site of struggle among individuals and groups vying to establish preferred meanings and uses of complex symbols. Thus, the perspective used in this article is similar to previous studies that have examined how institutional members have strategically appropriated various macro-social discourses to advance their more narrow organizational or bureaucratic interests. ${ }^{16}$ For Hardy, this perspective helps scholars to explain how macro-social discourses "appear" within organizational discourses "and, in so doing, legitimate them and enhance their performativity, through both unconscious and strategic processes". ${ }^{17}$ This perspective necessarily maintains a constructionist orientation to language, ${ }^{18}$ as well as a focus on texts as the "unit" of discourse analysis. ${ }^{19}$ Using this theoretical perspective, the next section explains how $9 / 11$ served as a catalyst for a historical transformation of U.S. educational exchange discourse.

\footnotetext{
12 D. Grant, C. Hardy, C. Oswick, and L. Putnam, eds., The Sage Handbook of Organizational Discourse (London: Sage, 2004).

Grant et al., The Sage Handbook, 3.

${ }^{14}$ N. Phillips and C. Hardy, Discourse Analysis: Investigating processes of social construction (Thousand Oaks, CA: Sage, 2002).

15 C. Hardy, "Scaling Up and Bearing Down in Discourse Analysis: Questions regarding textual agencies and their contex" Organization 11 (2004): 415-25.

16 C. Hardy, I. Palmer, and N. Phillips, "Discourse as a Strategic Resource" Human Relations 53 (2000): 1227-48; Simpson and Cheney, "Marketization, Participation"; R. Suddaby and R. Greenwood, "Rhetorical Strategies of Legitimacy," Administrative Science Quarterly 50 (2005): 35-67.

17 Hardy, "Scaling Up," 421.

18 P. L. Berger and T. Luckmann, The Social Construction of Reality: A Treatise in the Sociology of Knowledge (New York: Anchor, 1967).

19 Grant et al., The Sage Handbook, 3.
} 


\section{9/11 and the Strategic Value of Educational Exchange}

On its website, ECA provides "An Informal History of the Fulbright Program" that summarizes the ways in which the Fulbright Foreign Scholarship Board, the American academic community, and various binational commissions historically have viewed educational exchange in its foreign relations context:

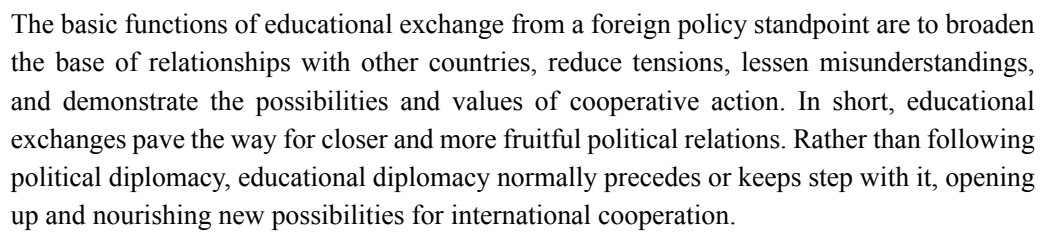

Despite its outstanding reputation and track record for promoting goodwill, mutual understanding, and peace, educational exchange is not a panacea for political intolerance and violent extremism. All four of the pilots of the hijacked aircraft on 9/11 had international educational experiences. Three of the pilots, Mohamed Atta (Egypt), Marwan al-Shehhi (United Arab Emirates), and Ziad Jarrah (Lebanon), had attended universities in Germany. The fourth pilot, Hani Hanjour (Saudi Arabia), had briefly attended the University of Arizona and had lived off-and-on in the United States over several years. Significantly, the mastermind of the 9/11 attacks, Khalid Sheikh Mohammed (Kuwait) had attended Chowan College in Murfreesboro, North Carolina, later transferring to North Carolina Agricultural and Technical State University, where he earned a Bachelor of Science in mechanical engineering in 1986. A CIA report later claimed that "Khalid Sheikh Mohammed's limited and negative experiences in the United States - including a short stay in jail - almost certainly helped propel him on his path to become a terrorist". ${ }^{20}$ Despite the 9/11 Commission's findings concerning the educational backgrounds of the attack's mastermind and pilots, the Final Report claimed: "The United States should rebuild the scholarship, exchange, and library programs that reach out to young people and offer them knowledge and hope. Where such assistance is provided, it should be identified as coming from the citizens of the United States". ${ }^{21}$

The theme of educational exchange-as-antidote-to-extremism would soon be codified within official discourse as U.S. lawmakers and officials turned to educational exchange as a resource in the fight against terrorism. Section 7112 of the Intelligence Reform and Terrorism Prevention Act of 2004, the law based on the 9/11 Commission's recommendations, stated:

(1) Exchange, scholarship, and library programs are effective ways for the United States Government to promote internationally the values and ideals of the United States. (2) Exchange, scholarship, and library programs can expose young people from other countries to United States values and offer them knowledge and hope. ${ }^{22}$

In an influential report on U.S. Strategic Communication, the Defense Science Board (DSB) noted, "From 1993 to 2001, overall funding for the State Department's educational and cultural exchange programs fell more than 33 percent - and exchanges in societies with significant Muslim populations has declined". ${ }^{23}$ The DSB was emphatic, "This must change.

20 D. Temple-Raston, "Khalid Sheikh Mohammed's isolated U.S. college days," NPR News, November 18, 2009, http://www. npr.org/templates/story/story.php?storyId=120516152.

21 "Final Report," National Commission on Terrorist Attacks upon the United States, accessed August 4, 2008, http://govinfo. library.unt.edu/911/report/911Report.pdf.

22 Intelligence Reform and Terrorism Prevention Act of 2004, Pub. L. No. 108-458, Stat. 3797 (2004), http://www.gpo.gov/ fdsys/pkg/PLAW-108publ458/html/PLAW-108publ458.htm.

${ }_{23}$ Defense Science Board, Report of the Defense Science Board Task Force on Strategic Communication (Washington, D.C.: Department of Defense, 2004), 58. 
Increased, expanded and targeted exchange programs must be significantly ramped-up under the new strategic communication function". ${ }^{24}$

Educational exchange gained prominence through numerous post-9/11 reports, laws, and recommendations; ${ }^{25}$ however, the tension between mutual benefit and self-advantage could not be reconciled. For example, the WMD Commission (2005), formed in the wake of the 2003 U.S.-led invasion of Iraq, noted in its final report how educational exchange data might directly support U.S. national security interests at the expense of the privacy of international students:

ICE [Immigration and Customs Enforcement] collects reams of data on foreigners entering the United States and manages the Student and Exchange Visitor Information System database, which includes information on foreign students studying in the United States. However, whether agencies like ICE are equipped to make this information available to the Intelligence Community in useable form remains unclear. ICE officials explained that they would not give other agencies unfettered access to their databases (despite those agencies' wishes) because of unspecified legal constraints. We find this September 10th approach to information sharing troubling... ${ }^{26}$

The WMD Commission's recommendation is representative of how 9/11 helped to redraw the acceptable limits of self-advantage within the educational exchange domain - $\mathrm{a}$ domain ostensibly developed for mutual understanding and benefit. As Campbell lamented, "The mobility of students, scholars and researchers has been severely threatened by the strictures of homeland security, while advocates of educational exchange argue its value in the ideological battle". ${ }^{27}$ In sum, following 9/11, educational exchange was enrolled as a strategic resource in the War on Terrorism and became a key plank of broader U.S. strategic communication efforts.

However, those efforts have suffered from officials' ill-fated attempts to downplay or deny the self-advantaging and hemispheric tendencies of U.S. strategic communication. Officials have attempted to manage these tensions, in part, through the development of the discourse of "engagement," that is, an approach to public diplomacy that emphasizes listening and dialogue. Notably, a 2009 White House report, undertaken at the direction of congress, entitled National Framework for Strategic Communication stated: "It is vital that the United States is not focused solely on one-way communication, which is why we have consciously emphasized the importance of 'engagement' - connecting with, listening to, and building long-term relationships with key stakeholders". ${ }^{28}$ In referencing "engagement," the National Framework for Strategic Communication evoked a "cocreational" public relations paradigm. The cocreational paradigm emphasizes "dialogic" activities that foreground the relationship between speaker and audience. ${ }^{29}$ Cocreational approaches view publics as "cocreators of meaning" and communication "as what makes it possible to agree to shared meanings, interpretations, and goals". ${ }^{30}$ Cocreational approaches maintain that publics "are not instrumentalized but instead are partners in the meaning-making process". ${ }^{31}$

24 Defense Science Board, Report of the Defense, 58 .

25 Campbell, "International Education".

26 Commission on the Intelligence Capabilities of the United States Regarding Weapons of Mass Destruction, Report to the President (Washington, D.C., March 31, 2005), 474, accessed August 3, 2008, http://www.gpo.gov/fdsys/pkg/GPO-WMD/pdf/GPOWMD.pdf.

27 Campbell, "International Education,"127.

28 The White House, National Framework for Strategic Communication (Washington DC, 2009), 4, www.fas.org/man/eprint/ pubdip.pdf.

29 M. L. Kent,and M. Taylor, "Toward a Dialogic Theory of Public Relations," Public Relations Review 28 (2002): 21-37.

30 C. Botan, C. and M. Taylor, "Public relations: State of the field," Journal of Communication 54 (2004): 652.

31 Botan and Taylor, "Public relations: State of the field," 652. 
The National Framework for Strategic Communication describes engagement as "critical to allow us to convey credible, consistent messages, develop effective plans and to better understand how our actions will be perceived". ${ }^{32}$ However, both the strategy and its theoretical underpinnings cannot adequately account for stakeholders who believe that U.S. influence within their societies is fundamentally illegitimate. When attempting to engage with "extreme" audiences in the Arab world, for example, U.S. strategic communication reverts to largely one-way, asymmetric approaches that are based on a direct "media effects" ontology. ${ }^{33}$ The discourse of engagement thus elides the self-advantaging tendencies of actual communication practice. U.S. strategic communication efforts, including those conducted under the friendly moniker of "engagement," attempt to focus audiences' attention on America's values and away from its core strategic interests.

The effort of organizations to dialogically "engage" their stakeholders is not new, nor is its critique. Through the articulation of their "two-way symmetrical" model of public relations in 1984, Grunig and Hunt argued that "excellent" organizations use research and two-way communication to understand and foster dialogue with their stakeholders. ${ }^{34}$ Ideally, this dialogue leads to mutual understanding and mutually beneficial outcomes. Grunig and Hunt's model has served as the dominant theoretical (and normative) paradigm of public relations over the past two decades. U.S. public diplomacy and strategic communication nevertheless reveals consistent ambiguity as officials oscillate between images of communication as fundamentally "two-way" and mutually beneficial versus "one-way" and conduit-like. This oscillation contributes to U.S. officials' persistent inability to adequately account for the historical and structural inequalities within the regions where they conduct their work. This oscillation also contributes to the contradictions of U.S. "soft power" rhetoric. ${ }^{35}$

Given these conditions, in an article for International Communication Gazette, Comor and Bean critiqued what they termed "America's 'Engagement' Delusion". ${ }^{36}$ The Obama administration initially embraced engagement as the dominant concept informing U.S. public diplomacy. Yet, despite its emphasis on facilitating dialogue with and among Muslims overseas, Comor and Bean demonstrated that, in practice, engagement aimed to employ social media technologies to persuade skeptical audiences to empathize with U.S. policies. Engagement, Comor and Bean argued, actually perpetuated the communication-as-dominance underpinnings of U.S. strategic communication. Perhaps based on similar critiques, at the end of 2013, the word "engagement" was quietly removed from the U.S. State Department's definition of public diplomacy. ${ }^{37}$ However, the marketing-oriented, hemispheric tendencies of engagement live on in other sectors of government, including educational exchange.

\footnotetext{
32 The White House, National Framework, 1.

33 S. R. Corman, A. Trethewey, and H. L. Goodall, eds. Weapons of Mass Persuasion: Strategic communication to combat violent extremism (New York: Peter Lang Publishing, 2008).

34 J. E. Grunig and T. Hunt, Managing Public Relations (New York: Holt, Rinehart \& Winston, 1984).

35 C. Hayden, The Rhetoric of Soft Power: Public diplomacy in global contexts (Lanham, MD: Lexington Books, 2012).

36 E. Comor and H. Bean, “America's "Engagement" Delusion: Critiquing a public diplomacy consensus," International Communication Gazette 74 (2012): 203-220.

37 "Engaging" seems to have disappeared from one of the State Department's definitions of public diplomacy," John Browns Note's and Essays, December 21, 2013, http://johnbrownnotesandessays.blogspot.com/2013/12/engaging-seems-to-havedisappeared-from.html.
} 


\section{The Marketization of Educational Exchange at ECA}

The mission of ECA is to foster mutual understanding between the people of the United States and the people of other countries to promote friendly and peaceful relations. ECA accomplishes this mission through academic, cultural, sports, and professional exchanges that engage youth, students, educators, artists, athletes, and rising leaders in the United States and more than 160 countries. In 2010, about one quarter of ECA program participants were U.S. citizens; the rest were foreign nationals. ECA is home to the Fulbright Program, "the flagship international educational exchange program sponsored by the U.S. government ... designed to increase mutual understanding between the people of the United States and the people of other countries." Along with the Fulbright Program, featured prominently on ECA's website is a section titled "Impact." In this section, readers can learn how ECA "fosters cross-cultural understanding and supports top talent" by viewing visual representations of ECA's impressive growth and expansion. For example, from 2008 to 2010, ECA exchange participants increased 25 percent, from 46,415 to 57,801. Of 1 million program alumni, 364 are current or former heads of state, 55 are Nobel Prize winners, and eight are current or former United Nations ambassadors. Visitors to ECA's website thus confront overwhelming evidence of ECA's success.

That evidence is also prominently featured on the Alliance for International Educational and Cultural Exchange's website. The Alliance is an association of 86 nongovernmental organizations comprising the international educational and cultural exchange community in the United States. The Alliance claims:

Exchanges are an essential element in our smart power strategy to maintain and strengthen U.S. global leadership. Exchanges enhance U.S. national security and prosperity by building personal connections, mutual understanding, and productive partnerships that help us address critical global issues: managing the world economy, combating terrorism and regional conflicts, and dealing with environmental, public health, and humanitarian challenges. ${ }^{38}$

The Alliance cites several ECA figures to support its claim. Specifically, "98\% of Fulbright Visiting Scholar Program respondents reported that their Fulbright experiences gave them a deeper understanding of the United States, while 93\% believed their experiences heightened their awareness of social and cultural diversity among different nations". ${ }^{39}$ Additionally, "97\% of International Visitor Leadership Program (IVLP) alumni respondents agreed that the program develops friendly and peaceful relations between the United States and other countries". ${ }^{40}$ Such eye-popping figures suggest that ECA's programs are beyond reproach. However, the nearly universal belief in ECA programs' effectiveness raises the question of just what, exactly, is being evaluated. ECA's figures give the impression that educational exchange provides the quintessential remedy to ignorance and intolerance. A critical perspective, however, asks whether mutual understanding can be improved by closely examining the experiences of the handful of educational exchange participants who, apparently, do not agree that ECA programs heighten awareness of social and cultural diversity nor help develop friendly and peaceful relations. Because such critical inquires appear to be off the table, evaluation practices at ECA may miss an opportunity to truly deepen mutual understanding.

\footnotetext{
38 "The Impact of International Exchange Programs," Alliance for International Educational and Cultural Exchange, http:// www.alliance-exchange.org/sites/default/files/civicrm/2_Impact $\% 20$ of $\% 20$ exchanges.pdf

39 "The Impact of International Exchange Programs".

40 "The Impact of International Exchange Programs".
} 
Prior to the 1990s, market-oriented principles did not play a prominent role in educational exchange discourse. ${ }^{41}$ However, educational exchange's post-9/11 enrollment as a strategic communication resource brought it further into the realm of marketization. As a result, the discourse of educational exchange has subtly shifted from one of mutual understanding, goodwill, and peace to one of "impact," "effectiveness," and "accountability." The ways that educational exchange contributes to the economic, political, and social goals of its primary funder - the U.S. federal government — have gained currency.

The marketization of educational exchange has been driven, in part, by the wider push across government for "accountability." In 2009, the U.S. Government Accountability Office (GAO) found that, in return for $\$ 10$ billion worth of communication initiatives (its estimate of total strategic communications spending since 9/11), "limited data exist on the ultimate effect of U.S. outreach efforts". ${ }^{42}$ The GAO explained that agencies cited three challenges in measuring the effectiveness of their strategic communication efforts:

First, strategic communications may only produce long-term, rather than immediate, effect. Second, it is difficult to isolate the effect of strategic communications from other influences, such as policy. Third, strategic communications often target audiences' perceptions, which are intangible and complex and thus difficult to measure. ${ }^{43}$

Despite these difficulties, the GAO recommended market-oriented means of assessing public diplomacy, e.g., "private-sector measurement techniques" that included "the use of surveys and polling to develop baseline data, immediate follow-up research, and additional tracking polls to identify long-term changes over time". ${ }^{44}$

Following Simpson and Cheney, there are several potential outcomes stemming from the influence of GAO's marketization discourse vis-à-vis educational exchange evaluation. ${ }^{45}$ First, educational exchange organizations can simply adopt market-oriented vocabulary to refer to earlier practices. For example, officials may announce a new focus on "accountability" for departments while those departments may simply conduct business as usual. The second level of influence is what Simpson and Cheney call "the cafeteria approach," whereby organizations adopt or appropriate marketization practices in ways that affirm regional, local, or organization-specific practices. The third level of influence involves the wholesale transformation of an organization. Here, the pretense of non-market concerns is dropped in favor of privatization or market-based regulation. At ECA, developments currently resemble the first and second outcomes.

As within the domains of strategic communication and public diplomacy, at ECA, a risk is that marketization operates as a "universal discourse that permeates everyday discourses but goes largely unquestioned". ${ }^{66}$ Although it is not necessarily antithetical to the development of mutual understanding, peace, and goodwill, marketization tends to naturalize and legitimate a set of business-oriented commitments, practices, and ways of conceptualizing and talking about educational exchange that subordinate intangible outcomes to market-oriented logic.

For example, as the head of ECA, Assistant Secretary, Evan Ryan, recently remarked in several speeches provided on ECA's website, "Our programs need to be more flexible,

${ }^{41}$ Campbell, "International Education".

42 U.S. Government Accountability Office, U.S. Public Diplomacy: Key issues for congressional oversight, GAO-09-679SP (Washington, DC, 2009), 2.

43 U.S. Government Accountability Office, U.S. Public Diplomacy, 16.

44 U.S. Government Accountability Office, U.S. Public Diplomacy, 17.

45 Simpson and Cheney, "Marketization, Participation".

46 Simpson and Cheney, "Marketization, Participation," 191. 
responsive, agile, impactful, and innovative....America must do better if we want our young people to be able to compete in a globalized world," 47 Secretary Ryan declared. Secretary Ryan asked, " $[\mathrm{H}]$ ow many vulnerable youth learned that there are alternatives to terrorism because they were exposed to critical thinking skills?" For Secretary Ryan, the discourse of mutual understanding, peace, and goodwill has evolved into a commitment to "building relationships that create resilient communities, democratic societies, and a world where countries are primed to work together to solve our most vexing problems." Secretary Ryan also recently noted that President Obama "recognizes that it [educational exchange] can no longer be an afterthought, or something we do because it's nice. It needs to be integrated into our foreign policy strategy at the ground floor." Invoking the strategic dimension of educational exchange, Secretary Ryan stated, "International exchanges are the secret weapon of foreign policy and we must be on the cutting edge." Secretary Ryan's discourse illustrates how ECA's mission and goals have become inflected in marketization's vernacular of bottom lines, innovation, and problem solving.

Marketization discourse increasingly involves an emphasis on measurement and evaluation. For example, the Public Relations Society of America (PRSA) recently launched a campaign that urged communication professionals to make the "business case" for public relations. Seemingly ahead of the trend, evaluation comprises its own division at ECA. This Division aims to enhance the effectiveness of ECA's educational and cultural programs, and its work consists of two types of initiatives: evaluations and performance measurement. ECA claims that its evaluations are "retrospective and encompass cross-cutting themes" and "incorporate case studies to highlight findings" to "provide data for program planning and goal setting". ${ }^{8}$ Performance measurement initiatives, by contrast, "monitor the Bureau's programs to track results," "establish baselines and collect end-of-program and followup data from participants," "compare data across the three points to assess effectiveness," and "provide data for program planning and goal setting". ${ }^{49}$ In addition to evaluations and performance measurement, ECA also provides visitors to its website "Resources and Tools" to guide evaluation and performance measurement efforts. These resources include performance measurement and evaluation presentations and research papers, external materials, a bibliography of work in the field, and other information.

There are five presentations listed on the Evaluation Division's website. These include: "Defining Outcomes and Goals;" "ECA Evaluation: Assessing Public Diplomacy;" "Monitoring and Evaluation;" "Performance Measurement for Program Officers," and "Planning and Monitoring at Program Level." ${ }^{50}$ The presentation, "Defining Outcomes and Goals," authored in 2009 by ECA's Chief of Evaluation, provides a five-part model for evaluation. "Planned work" entails a combination of (1) "inputs" and (2) "activities." These, in turn, lead to "intended results," i.e., (3) "outputs," (4) "outcomes," and (5) a "goal" ${ }^{51}$ The model helps evaluators avoid confusing outcomes and goals with activities,

\footnotetext{
47 “Assistant Secretary Evan Ryan's Remarks at Fletcher School of Law and Diplomacy,” Bureau of Educational and Cultural Affairs, http://eca.state.gov/speech/assistant-secretary-evan-ryans-remarks-fletcher-school-law-and-diplomacy\#sthash.Kygm0L8T. dpuf.

48 "Evaluation at ECA," Bureau of Educational and Cultural Affairs, http://eca.state.gov/impact/evaluation-eca.

49 "Evaluation at ECA," Bureau of Educational and Cultural Affairs, http://eca.state.gov/impact/evaluation-eca.

50 "Resources and Tools," Bureau of Educational and Cultural Affairs, http://eca.state.gov/impact/evaluation-eca/resourcesand-tools

51 U.S. Department of State, Bureau of Educational and Cultural Affairs (ECA), Alumni Outreach Plans: Defining Outcomes and Goals, report prepared by Robin Silver (December 2009),10, http://eca.state.gov/files/bureau/defining_outcomes_goals_ dec2009.pdf.
} 
and it aids officials in determining "whether inputs are being used as intended, outputs are occurring, and outcomes and goals are being achieved". This vocabulary reappears in another presentation, "ECA Evaluation: Assessing Public Diplomacy." In this presentation, authored in 2010, audiences are told that ECA conducts evaluation and performance measurement for four reasons. First, it "ensures programs are effective in achieving State Department, ECA, and program goals". Second, it helps ECA meet "Congressional, OMB, other mandates for evaluation, PM, and results reporting". Third, it "provides data for use by program managers and grantees". And finally, it "contributes to [the] body of knowledge for practitioners and scholars across sectors". ${ }^{52}$ ECA evaluations are thus conducted primarily to demonstrate to officials and funders that ECA's programs are effective. However, the stated goal of using evaluations to contribute to the body of knowledge for practitioners and scholars opens a door to more critical and reflexive perspectives.

As of August 2014, 34 completed evaluations are available via ECA's website. Of these 34 evaluations, none contain in-depth discussion of participants' negative experiences. Almost no criticism of the United States, its people, or way of life is to be found in any of the evaluation reports. For example, the evaluation for the Youth Exchange and Study Program (YES) provides a typical passage:

Upon completing the program and a year after returning home, a large majority of participants had a 'more favorable' view of Americans as a result of their YES experience. The most important thing they felt they learned about Americans is that they are friendly, kind, helpful, open-minded and tolerant. Many commented on how friendly and welcoming Americans are to foreigners, such as YES students. ${ }^{53}$

While some participants' negative experiences are occasionally alluded to, these cases are not explored in any substantive way. Educational exchange is not evaluated in order to identify the ways in which negative experiences might inadvertently contribute to antipathy toward the United States. It is also possible that participants who report favorable responses nevertheless harbor distrust or skepticism of U.S. foreign policy. In general, ECA's evaluations decouple program experiences from foreign policy-oriented concerns. Seldom are policyrelated questions even asked. Measurement of participants' perceived "understanding" or "view" of Americans should not be conflated with an embrace of American values nor support for U.S. government policies.

Educational exchange evaluation at ECA, as it is currently conceptualized, aims to prove to funders that programs bolster America's positive image and reputation. While an implicit objective of educational exchange is for foreign participants to become more accommodating, understanding, or supportive of U.S. economic, political, social, or technological interests, values, and aims, there are clear limits to exchange. Rarely is it suggested that the values of others might inform how Americans view and conduct themselves in a globalized world.

In sum, consideration should be given to how ECA's evaluation techniques make sense in light of growing anti-U.S. extremism. As Comor and Bean have suggested, stakeholders ought to consider the possibility that uncritical and narrow means of evaluating educational

52 U.S. Department of State, Bureau of Educational and Cultural Affairs (ECA), Public Diplomacy Assessment: ECA Program Evaluation and Performance Measurement (April 2010), 5, https://eca.state.gov/files/bureau/eca_evaluation_assessing-publicdiplomacy_apr2010.pdf.

53 "Evaluation of the youth exchange and study program," InterMedia, http://eca.state.gov/files/bureau/youth-exchange-andstudy-yes-full-report-aug-2009.pdf, 5 . 
exchange may itself entrench a kind of myopia. ${ }^{54}$ If educational exchange is evaluated using limited snapshots that overwhelmingly showcase positive benefits, officials could be hindered in their ability to even recognize the ways that educational exchange might in some cases inadvertently contribute to negative international sentiment or political extremism. More to the point, such evaluations may subtly evoke a causal relationship between educational exchange and support for U.S. foreign policy that is not empirically supported. The marketization of U.S. educational exchange at ECA thus reflects and reinforces a hemispheric approach U.S. strategic communication that impedes the development of more critical, reflexive, and democratic conceptualizations of U.S. public diplomacy.

\section{Conclusion}

Recently, the United States Advisory Commission on Public Diplomacy (ACDP) released a report, "Data-Driven Public Diplomacy Progress Towards Measuring the Impact of Public Diplomacy and International Broadcasting Activities," that supports the arguments contained in this essay. In its report, ACDP claimed that State Department officials needed to better recognize the importance of research in public diplomacy, reform risk-averse organizational cultures, develop more consistent strategic approaches to evaluation, increase training, and boost funding. ${ }^{55}$

According to ACDP, evaluation activities at ECA in 2013 totaled \$1.3 million, which is less than .25 percent of ECA's total budget. It is therefore unsurprising that ACDP found considerable room for improvement, despite lauding ECA for its evaluation efforts within existing constraints. Specifically, ACDP recommended that evaluators at ECA: "(1) connect program objectives with research design; (2) separate short-term from long-term goals; (3) avoid reports that rely on self-evaluation data; (4) supply greater context of country, regional and global trends; (5) encourage constructive criticism through evaluations; (6) clarify descriptions of research processes; and (7) distinguish between what's inferred versus what is directly assessed or observed". ${ }^{56}$ ACDP's fifth recommendation closely aligns with this essay's argument. In reviewing ECA's publicly available evaluations, ACDP similarly concluded that ECA's reports "provided a strikingly positive view of performance measures, which focused on self-reported changes in participants and included positive quotes from participants who filled out the surveys" ${ }^{57}$ Notably, however, ACDP did not explicitly call for ECA to investigate negative cases; rather ACDP urged ECA to conduct "more objective data analysis" in order to detect and understand "the reasons for both the formation of and shifts in attitudes and behavior among foreign publics toward the United States". ${ }^{58}$ ACDP's recommendation is a helpful and necessary first step; however, in absence of a mandate for more critical and reflexive investigations, ECA officials will likely avoid exploring information from program participants that could challenge taken-for-granted assumptions, policies, and practices. The point of critical and reflexive investigation is to promote self-

${ }^{5}$ Comor and Bean, “America's 'Engagement' Delusion".

55 "Data-Driven Public Diplomacy Progress Towards Measuring the Impact of Public Diplomacy and International Broadcasting Activities," United States Advisory Commission on Public Diplomacy, September 16, 2014, http://www.state.gov/ documents/organization/231945.pdf.

56 "Data-Driven Public Diplomacy," 29.

57 "Data-Driven Public Diplomacy," 32.

58 "Data-Driven Public Diplomacy," 32. 
discovery and self-knowledge; it is not to convince audiences of the overwhelming success of a particular program.

ACDP's recommendation aside, marketization at ECA is likely to endure due to the entrenchment of the promotional framing of evaluation, the cost and time of evaluation, institutional inertia, and the discomfort that arises when officials confront voices critical of their efforts. This article's recommendation could certainly spark defensiveness and a counterargument that academics lack awareness of ECA's day-to-day constraints that delimit what evaluation practices are possible. Overcoming reactionary responses is necessary if officials are to meaningfully reduce foreign audiences' suspicions of U.S. aims and intentions. Fear of being rhetorically attacked, confronted with conspiracy theories, or forced to account for historical examples of U.S. hypocrisy likely keep officials from engaging in international fora where communication is not carefully scripted or controlled. The development of critical and reflexive evaluation practices might therefore demonstrate goodwill, honesty, and a genuine interest in listening to and responding to the wants, interests, and needs of foreign audiences. In theoretical terms, such evaluation practices would do much to promote dialogic communication's principles of mutuality, propinquity (shared bonds), empathy, risk, and commitment. ${ }^{59}$

This article has considered how marketization discourse promotes a particular kind of evaluation process that inadvertently hinders the development of deeper mutual understanding, transformation, and peace. Similar to the tensions and contradictions associated with the strategy of "engagement," commitment to mutual understanding requires the development of critical insight, genuine dialogue, and reflexivity. Analysis of ECA evaluation presentations and reports suggests that a "customer orientation" characterizes ECA's approach to educational exchange. ${ }^{60}$ This orientation necessarily reflects and influences the way that stakeholders conceptualize public diplomacy. ECA's orientation potentially undermines critical exploration of educational exchange programs that have failed to produce desired outcomes for specific individuals. While negative individual cases may be rare, investigation of those cases could help officials and citizens develop a more comprehensive and nuanced understanding of the benefits, risks, and consequences of educational exchange. Customercentric discourse encourages officials to downplay or ignore negative cases in favor of evaluation data that satisfies customers' demands, paints programs in the best light, and promotes expanded funding and operations.

ECA notes that independent evaluation firms conduct its evaluations, but when evaluation is performed principally to showcase success, it loses some of its supposed objectivity. At worse, evaluation instead "functions to reassure, exonerate, and glorify" the organization that has paid for it. ${ }^{61}$ Within a marketization paradigm, the products of evaluation risk becoming self-serving: The goal of increased mutual understanding becomes subordinated to the goal of bureaucratic continuance and resource accumulation. While the marketization of relations among government agencies is designed to improve efficiency and effectiveness, marketization discourse discounts a perspective that views public diplomacy as a taxpayersupported function with a responsibility to critically inform not just other federal agencies,

\footnotetext{
59 Kent and Taylor, "Toward a Dialogic Theory".

60 Marcus, "'Would you like fries with that, Sir?"”

${ }_{61}$ R. P. Newman, “Communication Pathologies of Intelligence Systems," Speech Monographs 42 (1975): 274.
} 
congress, and the executive branch, but also scholars and citizens. ECA's own evaluation presentations indicate that possibilities for more critical engagement exist and can be cultivated. Asking evaluation questions that promote understanding of the potential risks and consequences of educational exchange should therefore be on the table.

\section{Acknowledgements}

The author thanks Dr. Edward Comor for his influence in the development of this essay.

\section{Bibliography}

Alliance for International Educational and Cultural Exchange. "The Impact of International Exchange Programs." http://www.alliance-exchange.org/2014-position-papers.

Berger, P. L., and T. Luckmann. The Social Construction of Reality: A Treatise in the Sociology of Knowledge. New York: Anchor, 1967.

Botan, C., and M. Taylor. "Public relations: State of the field." Journal of Communication 54, no. 4 (2004): 645-61.

Bureau of Educational and Cultural Affairs. "Assistant Secretary Evan Ryan's Remarks at Fletcher School of Law and Diplomacy." http://eca.state.gov/speech/assistant-secretary-evan-ryans-remarks-fletcher-school-law-anddiplomacy\#sthash.Kygm0L8T.dpuf.

— . "An informal history of the Fulbright Program." http://eca.state.gov/fulbright/about-fulbright/history/ early-years.

— . "Evaluation at ECA." http://eca.state.gov/impact/evaluation-eca.

"Resources and Tools." http://eca.state.gov/impact/evaluation-eca/resources-and-tools.

_ . "Evaluation of the youth exchange and study program." http://eca.state.gov/files/bureau/youth-exchangeand-study-yes-full-report-aug-2009.pdf.

Campbell, D. "International education and the impact of the 'War on Terrorism'." Irish Studies in International Affairs 16 (2005): 127-54.

Commission on the Intelligence Capabilities of the United States Regarding Weapons of Mass Destruction. Report to the President. Washington, D.C., March 31, 2005. Accessed August 3, 2008. http://www.wmd.gov/report.

Comor, E., and H. Bean. "America's 'Engagement' Delusion: Critiquing a public diplomacy consensus." International Communication Gazette 74 (2012): 203-20.

Corman, S. R., A. Trethewey, and H. L. Goodall, eds. Weapons of Mass Persuasion: Strategic communication to combat violent extremism. New York: Peter Lang Publishing, 2008.

Defense Science Board. Report of the Defense Science Board Task Force on Strategic Communication. Washington, D.C.: Department of Defense, 2004.

Grant, D., C. Hardy, C. Oswick, and L. Putnam, eds. The Sage Handbook of Organizational Discourse. London: Sage, 2004.

Grunig, J. E., and T. Hunt. Managing Public Relations. New York: Holt, Rinehart \&Winston, 1984.

Gygax, J., and N. Snow. "9/11 and the Advent of Total Diplomacy: Strategic communication as a primary weapon of war." Journal of 9/11 Studies 38 (2013): 1-29.

Hardy, C. "Scaling Up and Bearing Down in Discourse Analysis: Questions regarding textual agencies and their context.” Organization 11 (2004): 415-25.

Hardy, C., I. Palmer, and N. Phillips. “Discourse as a Strategic Resource.” Human Relations 53 (2000): 1227-248.

Hayden, C. The Rhetoric of Soft Power: Public diplomacy in global contexts. Lanham, MD: Lexington Books, 2012.

Jensen, J. Ethical Issues in the Communication Process. New Jersey: Lawrence Erlbaum, 1997.

John Browns Note's and Essays. "Engaging” seems to have disappeared from one of the State Department's definitions of public diplomacy.” December 21, 2013. http://johnbrownnotesandessays.blogspot.com.tr/2013/12/engagingseems-to-have-disappeared-from.html. 
Kent, M. L., and M. Taylor. “Toward a Dialogic Theory of Public Relations.” Public Relations Review 28 (2002): 21-37.

Leitch, S., and S. Davenport. "The Politics of Discourse: Marketization of the New Zealand science and innovation system.” Human Relations 58 (2005): 891-912.

Marcus, A. I. "“Would you like fries with that, Sir?' The evolution of management theories and the rise and fall of total quality management within the American federal government." Management \& Organizational History 3 (2008): 311-38.

McKie, D., and D. Munshi. Reconfiguring Public Relations: Ecology, equity, and enterprise. London: Routledge, 2007.

Moloney, K. Rethinking Public Relations. New York: Routledge, 2006.

National Commission on Terrorist Attacks upon the United States. "Final Report." Accessed August 4, 2008. http:// www.9-11 commission.gov/.

Newman, R. P. “Communication Pathologies of Intelligence Systems.” Speech Monographs 42 (1975): 271-90.

Phillips, N., and C. Hardy. Discourse Analysis: Investigating processes of social construction. Thousand Oaks, CA: Sage, 2002.

Simpson, M., and G. Cheney. "Marketization, Participation and Communication within New Zealand Retirement Villages: A critical-rhetorical and discursive analysis.” Discourse and Communication 1 (2007): 191-222.

Suddaby, R., and R. Greenwood. "Rhetorical Strategies of Legitimacy." Administrative Science Quarterly 50 (2005): 35-67.

Temple-Raston, D. “Khalid Sheikh Mohammed's isolated U.S. college days.” NPR News, November 18, 2009. http://www.npr.org/templates/story/story.php?storyId=120516152.

The White House. National Framework for Strategic Communication. Washington D.C., 2009. www.fas.org/man/ eprint/pubdip.pdf.

United States Advisory Commission on Public Diplomacy. "Data-Driven Public Diplomacy Progress Towards Measuring the Impact of Public Diplomacy and International Broadcasting Activities." September 16, 2014. http://www.state.gov/documents/organization/231945.pdf.

U.S. Department of State. Bureau of Educational and Cultural Affairs (ECA). Alumni Outreach Plans: Defining Outcomes and Goals. December 2009. http://eca.state.gov/files/bureau/defining_outcomes_goals_dec2009.pdf.

- Bureau of Educational and Cultural Affairs (ECA). Public Diplomacy Assessment: ECA Program Evaluation and Performance Measurement. April 2010. https:/eca.state.gov/files/bureau/eca_evaluation assessing-public-diplomacy_apr2010.pdf.

U.S. Government Accountability Office. U.S. Public Diplomacy: Key issues for congressional oversight. GAO-09679SP. Washington, DC, 2009. http://www.gao.gov/new.items/d09679sp.pdf. 